\title{
Yeni Medya Çağında İlişki İnşası: Sanal Gerçeklik Teknolojisi ve Halkla İlişkiler Kampanyaları ${ }^{1}$
}

\author{
Ali Arıcı \\ Öğretim Görevlisi \\ Bilecik Şeyh Edebali Üniversitesi, Bozüyük MYO, \\ Pazarlama ve Dış Ticaret Bölümü \\ ali.arici@bilecik.edu.tr \\ Orcid: 0000-0003-4027-8288 \\ Özgür Kılınç \\ Doktor Araştırma Görevlisi \\ İnönü Üniversitesi, İletişim Fakültesi, Halkla İlişkiler ve Tanıtım Bölümü \\ ozgur.kilinc@inonu.edu.tr \\ Orcid: 0000-0002-8697-162X \\ Sevil Bayçu \\ Doçent Doktor \\ Anadolu Üniversitesi, İletişim Bilimleri Fakültesi, Halkla Ilişkiler ve Reklamclık \\ Bölümü \\ suzoglu@anadolu.edu.tr \\ Orcid: 0000-0003-0865-6007
}

\section{Abstract \\ Relationship Building in the New Media Age: Virtual Reality Technology and Public Relations Campaigns}

The brands that integrate the opportunities offered by the new media technologies, that have come into our lives in the 1960s and beyond, are not unconcerned to virtual reality technology that bring advantages such as "diversification of forms of telling stories / transferring content", "exploring experiential, psychological and interactive ways to reach the target audience", "provide more concentrated experiences through effects such as isolation and abstraction", "designing different techniques and environments in media relations", "more effective communication / relationship with target groups by creating innovative brand sense." With the investments made by expert international brands such as Apple, Facebook, Google, Samsung and Sony, virtual reality technology, as

1 19-20 Nisan 2018 tarihlerinde Ankara Üniversitesi Iletişim Fakültesi ev sahipliğinde Prof. Dr. Alâeddin Asna anısına düzenlenen "Yeni Zamanlar ve Halkla Ilişkiler" konferansında "Yeni Medya Çağında ilişki Inşası: Sanal Gerçeklik Teknolojisi ve PR Kampanyaları" başlığıyla sunulan bildirinin genişletilmiş ve gözden geçirilmiş halidir.

DOI: $10.16878 / g$ suilet.442965 
one of the "newest" faces of the new media, has become increasingly important and brings digital public relations applications to the agenda. In this context, the content and discourse on the surface is analysed by compiling the successful campaign examples that developed by brands using virtual reality technology. Based on history, advantages and devices of virtual reality in this study, by writing "best VR PR campaigns" and "VR PR campaigns" keywords on Google -the most used search engine in the world- the VR campaigns of five brands on the first page of Google were selected with purposeful sampling and analysed. In the campaigns, it was seen that the effects of VR technology such as immerse, interaction and imagination were prominent. In the context of content, transformational language, the emphasis of the cultural codes, emotional engagement and social responsibility theme has been determined.

keywords: public relations, virtual reality, relationship building, public relations campaigns

\section{Résumé}

\section{Création de relations à l'ère des nouveaux médias : campagnes sur les technologies de la réalité virtuelle et les relations publiques}

Les marques qui intègrent les possibilités offertes par les nouvelles technologies médiatiques qui sont entrées dans nos vies dans les années 1960 avec la compréhension de la communication, ne sont pas indifférent à la technologie de réalité virtuelle qui apporte des avantages tels que: "Raconter des histoires I diversifier les formes de transfert du contenu», Découvrir des moyens expérientiels, psychologiques et interactifs pour atteindre le public cible", "Offrir des expériences plus concentrées à travers des influences telles que l'isolement et I'abstraction", "Concevoir différentes techniques et environnements lors de relations avec les médias", "Créer une communication / relation plus efficace avec les masses cibles en créant une perception de marque innovante». La technologie de la réalité virtuelle qui gagne en valeur et en importance avec les investissements réalisés par des marques prometteuses à l'échelle internationale, telles que Apple, Facebook, Google, Samsung et Sony, apporte à l'ordre du jour I'application de relations publiques numériques comme I'un des "nouveaux" visages des nouveaux médias. Dans ce contexte des exemples de campagnes réussies développées en utilisant la technologie de réalité virtuelle des marques ont étés choisis et le contenu et les discours mis en avant sont étudiés. Dans l'étude basée sur l'histoire de la réalité virtuelle, les appareils et les avantages, un échantillonnage ciblé a été réalisé en écrivant les mots clés "best VR PR campaigns" et "VR PR campaigns" sur Google, le moteur de recherche le plus utilisé au monde et les campagnes VR de cinq marques apparues sur la première page ont été analysées. Au cours des campagnes, il a été constaté que les effets de la technologie de réalité virtuelle, tels que l'immersion, l'interaction et l'imagination, étaient prédominants. Dans le contexte du contenu, du langage transforma- 
tionnel, l'accent a été mis sur les thèmes des codes culturels, de l'engagement émotionnel et de la responsabilité sociale.

mots-clés: relations publiques, réalité virtuelle, création de relations, campagnes de relations publiques

\section{Öz}

\section{Yeni Medya Çağında İlişki İnşası: Sanal Gerçeklik Teknolojisi ve Halk- la İlişkiler Kampanyaları}

1960 ve sonrası süreçte hayatımıza giren yeni medya teknolojilerinin sunduğu imkanları iletişim anlayışlarıyla bütünleştiren markalar, "hikaye anlatma / içerik aktarma şekillerini çeşitlendirme", "hedef kitleye ulaşmada deneyimsel, psikolojik ve interaktif yollar keşfetme", "izolasyon ve soyutlama gibi etkiler sayesinde daha konsantre deneyimler sunabilme", "medya ile ilişkilerde farklı teknikler ve ortamlar tasarlama", "yenilikçi marka algısı yaratarak hedef kitleler ile daha etkili iletişim / ilişki kurabilme" gibi avantajları beraberinde getiren sanal gerçeklik teknolojisine de kayıtsız kalmamaktadır. Apple, Facebook, Google, Samsung ve Sony gibi uluslararası ölçekte söz sahibi markaların yaptıkları yatırımlarla değeri ve önemi artan sanal gerçeklik teknolojisi, yeni medyanın "en yeni" yüzlerinden biri olarak dijital halkla ilişkiler uygulamalarını gündeme taşımaktadır. Bu bağlamda çalışma kapsamında markaların sanal gerçeklik teknolojisini kullanarak geliştirdikleri başarılı kampanya örnekleri derlenerek yüzeye çıkan içerik ve söylemler araştırılmaktadır. Sanal gerçeklik tarihçesi, cihazları ve avantajları temelinde şekillenen çalışmada, amaçı örneklemle -dünyanın en çok kullanılan arama motoru olan- Google'a "best VR PR campaigns" ve "VR PR campaigns" anahtar sözcükleri yazılarak ilk sayfada çıkan beş markanın VR kampanyaları analiz edilmiştir. Incelenen kampanyalarda VR teknolojisinin içine dalmak, etkileşim ve hayal gücü olarak belirtilen etkilerinin öne çıktığı görülmüştür. Içerik bağlamında ise transformasyonel dilin, kültürel kodların, duygusal bağlılığın ve sosyal sorumluluk temasının belirginliği saptanmıştır.

anahtar kelimeler: halkla ilişkiler, sanal gerçeklik, ilişki inşası, halkla ilişkiler kampanyaları 


\section{Giriş}

Kamular ile ilişki inşasında halkla ilişkiler uygulayıcıları çeşitli araçlar kullanmaktadır. Basın bültenleri, haber mektupları, kurumsal gazete, dergi ve kitap bu araçların geleneksel biçimini temsil ederken sosyal iletişim platformları ve çok daha güncel bir uygulama olan sanal gerçeklik ise halkla ilişkiler alanının araçsal anlamda daha yeni bir biçimini temsil etmektedir. Halkla ilişkiler bağlamında ilgili kamularla doğrudan ve simetrik bir yapıda iletişim kurmada ve bu iletişimi sürdürebilir kılmada dikkat çeken uygulamalardan biri de sanal gerçekliktir. Diğer bir deyişle tarihsel geçmişi 1960'lara kadar götürülebilse de 21. yüzyıl uygulaması olarak sanal gerçeklik kurumların, kamuları ile olan ilişkilerinde yönelebilecekleri araçlardan biridir.

Yeni medya araçlarıyla birlikte kurumların iletişim anlayışları ikna temelli bir yapıdan ilişki boyutuna taşınmakta ve kurumlar tarafından teknolojinin vaat ettiği deneyim değeri ön plana çıkarımaktadır. Yeni medyanın sunduğu etkileşim dili sürdürülebilir ilişki arayışına zemin hazırlayarak kurumları hedef kitle algısında sadece birer form olmaktan kurtarabilmektedir.

Eğitim, sağlık, turizm, oyun, eğlence ve pazarlama gibi kullanım alanlarında popülerliği gün geçtikçe artan sanal gerçeklik (virtual reality: VR) teknolojileri ve uygulamaları araç ve platform tabanlı iletişim tasarımlarıyla ön plana çıkmaktadır. Bu bağlamda deneyim ekonomisinin bilgi çağı ile entegrasyonu, gerçeklik ve iletişim arasındaki iliş̧kiyi yeniden düşündürmektedir. Dolayısıyla iletişim trendlerini takip eden kurumlar pazarlama anlayışlarını güncelleştirerek hedef kitleler ile etkileşim temelinde buluşabilmektedir.

Bir yönetim fonksiyonu olarak halkla ilişkilerin uygulama alanları düşünüldüğünde özellikle pazarlama amaçlı halkla ilişkiler açısından marka farkındalığını oluşturmada, ilişki inşasında (Barnes, 2016, s. 22), marka deneyimini sunmada ve kurumların sosyal sorumluluk kampanyalarında sanal gerçeklik uygulamaları görünür bir nitelik kazanmaktadır. Bu kapsamda çalışmanın amaCı Displaced (Yerinden Edilmişler), Be Fearless \& Bedtime Stories (Korkusuz Ol \& Uyku Masalları), Experience the TOMS Virtual Giving Trip (TOMS Sanal Bağış Yolculuk Deneyimi), Christmas Ride \& Recycled Cardboard (Noel Yolculuğu \& Geri Dönüştürülmüş Gözlük) ve Clouds Over Sidra (Sidra'nın Üzerindeki Bulutlar) kampanyalarından hareketle sanal gerçeklik ve halkla ilişkiler arasındaki ilişkiyi tartışmaktır. Çalışma sanal gerçekliğin halkla ilişkiler alanındaki olası kullanım biçimlerini söz konusu kampanyalar üzerinden yorumlayıcı bir yaklaşımla değerlendirmektedir. Çalışmada öncelikle yeni medya ve sanal gerçeklik kavramlarına; ardından halkla ilişkilerde sanal gerçekliğin yerine değinilmekte; bu bölümleri ise yöntem, bulgular ve sonuç bölümleri takip etmektedir. 


\section{Yeni Medya ve Sanal Gerçeklik}

Internet, yeni bir zaman-mekansal bölge olan oradayı ve șimdiyi; yeni bir iletişim biçimi olan elektronik metin sohbetini ve yeni bir sosyal toplanma yeri olan çevrimiçi kamuya açık alanı ortaya çıkararak önemli değişimlere yol açmışıı (Zhao, 2006, s. 459). Yeni medya, İnternet, cep telefonları ve bloglar gibi iletişim ve ağ teknolojilerine dayanan medya biçimlerine atıfta bulunan, insanların dünyayı nasıl algıladıklarını ve anladıklarını değiştiren ve yaygın olarak kullanılan bir terimdir (Chen ve Ding, 2009, s. 367-368).

Insanlık tarihinde, fikirleri iletmek ve deneyimlemek için kullanılan medyanın gelişimi dikkat çekici bir özellik olup belki de bu gelişimin en son adımı ise sanal gerçekliğin kullanılmasıdır. Sanal gerçeklik, pratik uygulamaların ve iletişim kurmanın daha etkili yollarını bulmak için çok fazla deneyimin yer aldığı teknolojik ilerlemelerin getirdiği yeni bir ortamdır (Sherman ve Craig, 2003, s. 5).

1990'ların başından beri sanal gerçeklik kavramı medyada yaygın bir şekilde yer almaya başlamıştır (Wapler ve Stallkamp, 1998, s. 85). 1970'lerin ortalarında Myron Krueger, yapay gerçeklik terimini kullanmış; 1989'da ise bilgisayar bilimcisi Jaron Lanier ise yaratıcı, grafiksel, işitsel ve etkileşimli bir şey olarak nitelendirdiği sanal gerçeklik kavramını kullanmışır (Ma ve Choi, 2007, s. 32-33). Diğer yandan sanal gerçekliğin yeni bir buluş olmadığı, ilk sanal gerçeklik video arşivinin 1962'de Sensorama Simülatörü (Sensorama Simulator) adlı buluşuyla Morton Heilig'e ait olduğu belirtilmektedir (Burdea ve Coiffet (2003, s. 4). Sensorama Simülatörü, kullanıcıların motosikletler, bisikletler ve hatta helikopter ile önceden kaydedilmiş farklı sürüşlerden seçebilecekleri bir ekranın önüne oturmalarını sağlamış; 3 boyutlu fotoğrafların slaytlarını görüntülemek için geniş görüş alanı optiklerini ve stero ses ile koku ve rüzgar jeneratörlerini kullanmıştır. Öte yandan bu sistem neredeyse hiç etkileşim içermediğinden bu sistemde kullanıcı da pasif bir gözlemci konumunda olmuştur (Gutierrez vd., 2008, s. 4-5).

Heilig'in çalışmalarını ise 1965 'te Ivan Sutherland'ın; 1970'lerin başlarında Myron Krueger'in araştırmaları; 1978'de A. Lippman, Scott Fisher ve Massachusetts Institute of Technology'deki diğer araştırmacıların çalışmaları izlemiştir. 1980 'lerin ortalarında ise farklı teknolojiler ilk gerçek VR sistemini oluşturmak için birleşmiştir. Yine VR ürünlerini ticarileştirmeye yönelik ilk girişimler de 1980'lerin başlarında ortaya çıkmış; VPL Research, VR donanımlarını ve yazılımlarını geliştirmeye odaklanmış ilk şirketlerden biri olmuştur (Gutierrez vd., 2008). 21. yüzyılda ise bilgisayar teknolojisinde, grafikte ve el cihazlarında büyük bir gelişme yaşanması VR'ın günümüzdeki konumu üzerinde etkili olmuş (Bucher, 2018) ve bu aracın "ilk 21. yüzyıl aracı" olarak nitelendirilmesine neden olmuştur (Pimentel ve Teixeira, 1995).

VR, bilgisayar ortamında oluşturulmuş ve sanal ortam olarak adlandırılan bir üç boyutlu (3D) ortamın, bir kullanıcının gezinebileceği ve etkileşime girebileceği, 
kullanııının beş duyusunun bir veya daha fazlasının gerçek zamanlı simülasyonu ile sonuçlanması şeklinde tanımlanmaktadır (Guttentag, 2010, s. 638). Bir diğer tanıma göre ise VR, çoklu duyusal kanallar aracılığıyla gerçek zamanlı simülasyon ve etkileşimleri içeren son teknolojiye dayanan bir kullanıcı - bilgisayar arayüzü olup; bu duyusal türler ise görsel, işitsel, dokunsal ögeler ile koku ve tattır (Burdea ve Coiffet, 2003, s. 3).

Sanal gerçekliğin bağlı olduğu teknolojik yenilikler, gerçek zamanlı 3D bilgisayar grafikleri, geniş açlı stereoskopik ekranlar, görüntüleyici (kafa) izleme, el ve jest izleme, stereofonik ses, dokunsal geribildirim ve ses girişi / çıkışı olarak sıralanabilir (Gigante, 1993a, s. 15). Yine, deneysel psikoloji ve nörobiyoloji alanındaki gelişmeler de sanal gerçeklik çalışmalarını etkilemiştir (Fuch ve Guitton, 2011, s. 4).

Biocca (1992, s. 23), sanal gerçekliği "bir bilgisayarın veya başka bir aracın yarattığı ve kullanııının var olduğunu hissettiği bir ortam" olarak tanımlamaktadır. VR sistemleri ve radyo, televizyon gibi geleneksel medya arasındaki ana fark, sanal gerçeklik yapısının üç boyutlu olmasıdır. Dalma, var olma ve etkileşim, sanal gerçekliği diğer teknolojilerden ayıran özelliklerdir (Mandal, 2013, s. 305). VR teknolojisi, Samsung Gear VR gibi akıllı telefon özellikli cihazların kullanılabilirliği ile tüketiciler için daha erişilebilir bir hale gelmiştir (Kerrebroeck vd., 2017, s. 177).

Sanal gerçekliğin, sanal dünya, dalmak, duyusal geribildirim ve etkileşim olmak üzere dört temel unsuru bulunmaktadır. Sanal dünya belirli bir ortamın içeriği olup sadece kendi yaratıcısının zihninde var olabilir ya da başkalarıyla paylaşılarak dağıtılabilir. Sanal dünya genellikle bir ortam aracılığıyla belirgin hale gelen hayali bir yerdir; nesnelerin bir mekanda toplanması ve bu nesneleri yöneten kurallar ve ilişkiler hakkındaki bir açıklamadır (Sherman ve Craig, 2003, s. 5-6-7).

Dalmak unsuru ise alternatif bir gerçekliğe ya da bakış açısına dalmak olup zihinsel ve fiziksel dalma olarak ikiye ayrılmaktadır. Zihinsel dalma, derinden bir bağlıık olup ilginliği içermekte; fiziksel dalma ise bir araca bedensel olarak dahil olma ve teknolojinin kullanımıyla vücudun duyularının sentetik uyaranı anlamına gelmektedir. Bu bağlamda VR'ın ilişkili olduğu bir diğer kavram da mevcudiyet yani var olma duygusudur (Sherman ve Craig, 2003, s. 7-9).

Var olma, görüntü, ses ve dokunsal geri besleme gibi multimodal simülasyonların beyin tarafından işlendiği ve bazı faaliyetlerin gerçekleştirildiği uyumlu bir ortam olarak anlaşılmaktadır. Kullanıcı sanal bir ortamda bulunduğunun bilincinde olduğunda var olma durumu gerçekleşir. Örneğin, video oyunu oynayan bir kişi oyundaki dünyanın gerçek olmadığını bilmekte fakat kişinin içerisinde bulunduğu durumdan dolayı kişi gerçekmiş gibi davranmaya karar vermektedir (Gutierrez vd., 2008, s. 3).

Duyusal geribildirim, sanal gerçeklik için gerekli olup, VR sistemi katılım- 
cılara, fiziksel konumlarına göre doğrudan duyusal geribildirim sağlar. Son olarak sanal gerçekliğin, gerçek görünmesi için kullanıcı eylemlerine yanıt vermesi yani etkileşimli olması gerekmektedir (Sherman ve Craig, 2003, s. 10).

Burdea ve Coiffet'de (2003, s. 4) VR'ın "3I" olarak adlandırdıkları üç özelliğinin dalmak (immerse), etkileşim (interaction) ve hayal gücü (imagination) olduğunu belirtmektedir. Sanal gerçeklik sadece orta ya da üst seviyede bir kullanıcı arayüzü olmayıp aynı zamanda mühendislik, tıp ve askeri alanlar gibi alanlardaki gerçek problemlere çözüm sunan uygulamalara da sahiptir. Sanal gerçeklik geliştiricileri tarafından tasarlanan bu uygulamalar, bir uygulamanın belirli bir problemi ne ölçüde çözebileceği yani bir simülasyonun ne kadar iyi performans göstereceği, insanın hayal gücüne bağlı bir görünüm sergilemektedir (Burdea ve Coiffet, 2003, s. 4).

Insan deneyiminin genişletilmiş dünyasını inşa etmede gerçekliğin kendi başına yeni ortaya çıkan bir şekli olan sanal gerçeklik, dijital teknoloji aracılığıyla hem soyutlanmış bir materyal hem de nesnelleştirilmiş bir akıl olma özelliğini taşımaktadır (Yoh, 2001, s. 8). VR, tek bir sanal alanı paylaşan birçok kullanıcıyı barındırabilen etkileşimli ve katılımcı bir ortam olup kullanıcılarına artan algısal sadakat ile güç sunma potansiyeline ve bir görevin tamamlanmasında bilişsel yükü azaltarak kullanıcıların performansını artırma potansiyeline sahiptir (Gigante, 1993b, s. 14).

Sanal gerçeklik, bireylerin kendilerini sanal bir dünyaya kaptırmalarını sağlayan kısmen yeni bir teknoloji olup bu çoklu algılı teknoloji çeşitli alanlarda kullanılmaktadır (Mahrer ve Gold, 2009, s. 100). Video oyunlar, sanal dünyalar, eğitim, turizm, mimarlık, canlı etkinlikler, Web tarama ve kurumsal uygulamalar VR teknolojisinin kullanılabileceği alanlar arasındadır. Özellikle 3D görselleştirme interaktif öğrenme için önemli bir araç niteliğindedir. VR'ın dalma özelliği, öğrenmeyi daha ulaşılabilir ve etkili bir hale getirmektedir. Turizm alanında ise VR, bir uçağa binme zorunluluğu olmadan başka bir yerde olmanın deneyimini aktarmanın basit ve etkili bir yolunu temsil etmektedir. Yine VR, askeri kullanım için simülasyon ve eğitim; tıbbi teşhis ve eğitim ile mühendislik ve tasarım alanlarında da çeşitli uygulamalar sunmaktadır (Parisi, 2015, s. 8-9). Başarılı VR uygulamaları arasında petrol ve doğal gaz arama, bilimsel görselleştirme, mimari, uçuş simülasyonu, terapi, askeri eğitim, tema parkı-eğlence, mühendislik analizi ve tasarım incelemeleri yer almaktadır (Jerald, 2016).

Pazarlama alanında ise VR'ın özellikle deneyim pazarlaması bağlamında öne çıktığı belirtilebilir. Tüketicilere, belirli bir ürünü veya markayı satın almaları veya bunlara sahip olmaları durumunda nasıl hissedebileceklerini gösteren deneyim pazarlaması, belirli ürün özelliklerine veya ürün bilgisine odaklanmak yerine bir ürün veya marka kullanma deneyimine odaklanmaktadır (Kerrebroeck vd., 2017, s. 3). Söz konusu deneyimleme pratiğinde bir araç olarak VR kullanılabileceği gibi VR'ın kullanılabileceği alanlardan bir diğeri ise halkla ilişkilerdir. 


\section{Halkla iliş̧kilerde Sanal Gerçeklik}

Son 25 yılda yaşanan teknolojik yenilikler, halkla ilişkiler pratiğinin birçok yönünü değiştirmiştir (Johnson, 1997, s. 213). Internet, 1990'ların ortalarından itibaren halkla ilişkiler uygulamalarını önemli ölçüde etkilemiştir (Ye ve Ki, 2012, s. 409). İletişim profesyonelleri on yıldan fazla bir süredir, bir dizi sosyal medya platformunun ve yeni teknolojilerin ortaya çıkışını görmüşlerdir (Kent ve Saffer, 2014, s. 569). Uygulamalı bir yönetim ve iletişim disiplini olarak halkla ilişkiler, özellikle son on yıldır bilgi ve iletişim teknolojilerinden büyük ölçüde etkilenmiştir (Vercic vd., 2015, s. 142). Zamanla gelişen iletişim teknolojileri, halkla ilişkiler uygulayıcılarına mesajlarını iletmede önemli fırsatlar sunmaktadır (Sweetser, 2010, s. 294). Diğer bir deyişle sosyal medya, halkla ilişkiler uygulayıcılarına kamularla ilişki kurmak ve ilişkiyi geliştirmek için bir dizi araç sunmaktadır (Kelleher ve Sweetser, 2012, s. 105).

İnternet, sorun yönetimi, ilişki yönetimi, çevresel tarama ve diğer önemli halkla ilişkiler fonksiyonları için sınırsız fırsatlar içermektedir. Internet temelli iletişim araçlarının daha fazla ortaya çıkması ve popülerlik kazanması uygulayıcıların bu tür araçları anlamalarını ve kullanmalarını gerektirmektedir (Porter vd., 2007, s. 92). Teknoloji, kurumların çeşitli kamuların talep ve beklentilerine ulaşma, onları ikna etme, bilgilendirme ve onlara cevap verme pratiklerini etkilemiştir (Duhé, 2015, s. 153).

Sosyal iletişim platformlarının etkileşimli ve diyaloğa dayalı yapısının yanı sıra kamularla ilişki inşasında halkla ilişkiler uygulayıcılarının yönelebileceği araçlardan bir diğeri de sanal gerçeklik teknolojisidir. Halkla ilişkiler uygulayıcılarının neden VR'a yönelmeleri gerektiğinin gerekçeleri olarak;

- Daha uzun katılım süresi,

- Daha derin duygusal bağlılık,

- Artan güven,

- Karmaşık olanın basitleştirilmesi,

- Daha fazla bağlıık,

- Yoğun satış döngüsü gibi unsurlar sıralanabilir

(http://media.dmnews.com/documents/225/mslgroup_vr_ ebook_56132.pdf).

Yukarıdaki unsurlardan görüldüğü üzere halkla ilişkiler ve VR kesişiminde öne çıkan noktalar "katılım, bağlılık ve güven" dir. Bu bağlamda VR'ın aracı işlevi halkla ilişkiler alanının temel yapısını inşa eden güven kavramına atıfta bulunmakta ve halkla ilişkilerin, kamularla ilişki inşasındaki amaçlardan biri olan bağlılık oluşturma ve bunu sürdürülebilir kılma üzerinden somutlaşmaktadır.

Alaimo ise (2016) VR'ın, “hikayelerin anlatım biçimlerinin değişmesi, hedef 
kitlenin empati yapmasını sağlaması, zoraki izleyiciler / dinleyicilere içeriği iletmesi, gazetecilerle iletişime geçmeyi değiştirmesi, toplantıların yapısını değiştirmesi, markaları yenilikçi olarak konumlandırması ve teknoloji meraklısı hedef kitlelerle bağlantı kurması" gibi nedenlerden dolayı halkla ilişkilerde bir dönüşüme yol açabileceğini belirtmektedir.

VR'ın halkla ilişkiler alanında yol açabileceği dönüşümlerin ise muhtemelen halkla ilişkilerin en somut ve köklü uygulama alanlarından biri olan medya ilişkilerini, yine etkinlik planlama açısından toplantılardaki yapısal değişimi; kurumun öyküsünü kamulara iletme ile belirli hedef kitlelere ulaşma biçimini ve sosyal sorumluluk uygulamalarını içerdiği belirtilebilir.

Sosyal sorumluluk uygulaması kapsamında halkla ilişkiler alanında VR kullanımına verilebilecek bir diğer örnek ise UNICEF'in Clouds Over Sidra adlı kampanyasıdır. Bahsi geçen VR film, Ürdünıdeki 84.000 Suriyeli mülteciden biri olan ve Za'atari kampında okula giden on iki yaşındaki bir kız çocuğunun öyküsünü ele almakta, savaştan dolayı yerinden edilenlere yönelik empatiye ve savunmasızlığa odaklanmaktadır (Barnes, 2016, s. 26-46).

VR teknolojisi ve halkla ilişkilerin kesişim noktasında VR'ın halkla ilişkiler alanındaki olası kullanım alanları ise;

- Eğitimin daha anlamlı ve eğlenceli bir hale gelmesi: Yukarıda dile getirildiği gibi Toyota'nın güvenli araç sürümüne yönelik uygulamış olduğu sanal gerçeklik deneyimi sonrasında katılımcıların \%80'i bu deneyimin kendilerini daha dikkatli bir şekilde araç sürmeye yönelik teşvik ettiğini belirtmiştir.

- Markaların insani özellikler kazanması: Klasik videolarla kurum görüntülerine yer vermektense VR aracılığıyla deneyimlenen bir kurum ziyareti, tüketicilerin kurumun içerisindeymiş gibi ve kuruma daha yakın hissetmelerini sağlamaktadır.

- Ürün demolarının, ürüne daha yakın hissettirmesi,

- Marka vaadinin canlanması, olarak sıralanmaktadır (http://www. irispr.com/blog/pr-meets-vr-when-storytelling-becomes-virtual).

Halkla ilişkiler açısından VR'ın yeni bir ilişki biçimine aracılık etmesi bu teknolojiyi önemli bir hale getirmektedir. Katılım, bağlılık ve güven vurgusunu öne çıkarması; hikaye anlatımını daha deneyimsel kılması; empati oluşturmada bir işleve sahip olması ve kurumları / markaları insani bir yapıda sunup, temsil etmesi bu teknolojinin halkla ilişkiler açısından temel avantaj noktalarını oluşturmaktadır.

\section{Yöntem}

Halkla ilişkiler alanında çevrimiçi trend takibi yapmak, halkla ilişkiler ve VR arasındaki ilişkiyi irdelemek, sanal gerçeklik teknolojisini başarıyla kullanan halkla 
ilişkiler kampanyalarını belirlemek ve tartışmak amacıyla yapılan çalışmada Google verileri temel alınmıştır. Google Barometer Raporu'na göre Google kullanıcılarııın yüzde 90'ından fazlası sadece ilk sayfada yer alan sonuçlara odaklanmaktadır. Bu bağlamda çalışmada amaçlı örneklemle -dünyanın en çok kullanılan arama motoru olan- Google'a 15-16 Mart 2018 tarihleri arasında belirli aralıklarla "best VR PR campaigns" ve "VR PR campaigns" anahtar sözcükleri yazılarak ilk sayfada çıkan toplam sekiz kurumdan / markadan beşi amaçlı olarak seçilmiştir. Google'da ilk sayfada görüntülenen ve başarılı bulunan kampanyalar içerik ile söylem açısından halkla ilişkiler perspektifinde değerlendirilmeye çalışılmıştır.

Sanal gerçeklik kampanyaları "yorumlayıcı içerik analizi" yönteminden hareketle değerlendirilmiştir. Geleneksel içerik analizine bir alternatif olarak önerilen yorumlayıcı içerik analizi, çağrışımsal yorumlar üzerinde durmaktadır (Ahuvia, 2001, s. 145). Geleneksel içerik analizi, metinsel ögeleri saymayı içerirken; yorumlayıcı içerik analizi sayılabilen / sayılamayan ya da betimlenebilen / betimlenemeyen temaları ve fikirleri tanımlamayı içermektedir (Giarelli ve Tulman, 2003, s. 951).

İçerik analizi, gazete yazıları, televizyon ve radyo haberleri gibi medya metinlerini analiz etmede kullanılabileceği gibi fotoğraf, film ve televizyon imgeleri gibi görsel içerikleri analiz etmede de kullanılabilir (Seale ve Tonkins, 2012, s. 460). Içerik analizinde hem açık hem de örtük içerik, yorumlama ile ilişkilidir fakat her ikisinde yorumlar derinlik ve soyutlama düzeyine göre değişmektedir (Graneheim ve Lundman, 2004, s. 106).

Açık içerik, yüzeyde bulunan ve kolayca gözlemlenen içerik olup (Potter ve Levine-Donnerstein, 1999, s. 259); örtük içerik ise araştırmacı tarafından, derin yapısal anlamları ortaya çıkarmak için verilerin sembolik anlamını sorgulayan yorumlayıcı bir okuma gerektirmektedir (Berg, 2001). Başka bir anlatımla yorumlayıCı içerik analizi örtük anlamlar üzerinde durmakta; bu anlamları ise belirli bir bağlam içerisinde yüzeye taşımaktadır. Görsel içeriklerin, okuyucuların / izleyicilerin yorum yapmalarına zemin sunan yapısı (Heisley, 2001) ve her metinde yorumlanması ve açıklanması gereken mesajların bulunması (Graneheim ve Lundman, 2004, s. 106) aynı zamanda birer metin olma niteliği de bulunan bu görsel içeriklerin yorumlayıcı bir perspektifle değerlendirilmesini anlaşıır kılmaktadır.

Araştırma kapsamında seçilen kampanyalar yorumlayıcı analizin yapısına uygun olarak çeşitli genellemeler yapmak yerine birtakım kavrayışlar sunmak amacıyla seçilmiştir (Merkl-Davies vd., 2011, s. 29). Kampanyaların incelenmesinde VR'ın 3l etkisini betimleyen içine dalmak, etkileşim ve hayal gücü işlevlerinin yanı sıra kişiselleştirilmiş pazarlama anlayışı, simetrik dil, hikaye anlatma şekli, empati gücü, güven tesisi ve duygusal çekicilik gibi halkla ilişkiler kampanyaları ile ilişkili kavramlardan yararlanılmıştır. Kampanyalarda öncelikle senaryoya veya hikayeye değinilmiş, ardından bahsi geçen işlevlerden ve kavramlardan hareketle halkla ilişkiler ve VR bağlamlı yorumlara yer verilmiştir. Diğer bir ifadeyle kam- 
panyalar daha sınırlı bir bağlamdan, daha geniş bir bağlama (Mayring, 2014, s. 65) doğru incelenerek kampanyalardaki anlamlar dizisi keşfedilmeye (Hsieh ve Shannon, 2005, s. 1285) çalışılmıştır.

\section{Bulgular ve Yorum}

Halkla ilişkiler ve sanal gerçeklik arasındaki ilişkiyi tartışmayı amaçlayan bu çalışmanın bulgular ve yorum kısmında Displaced (Yerinden Edilmişler), Be Fearless \& Bedtime Stories (Korkusuz Ol \& Uyku Masalları), Experience the TOMS Virtual Giving Trip (TOMS Sanal Bağış Yolculuk Deneyimi), Christmas Ride \& Recycled Cardboard (Noel Yolculuğu \& Geri Dönüştürülmüş Gözlük) ve Clouds Over Sidra (Sidra'nın Üzerindeki Bulutlar) olmak üzere beş halkla ilişkiler kampanyası incelenmiştir.

\section{The New York Times: “Displaced"}

The New York Times Magazine ve VRSE ortaklığı ile yaratılan Displaced (Yerinden Edilmişler) kampanyası, 360 derece görüntü teknolojisini kullanarak anlatmak istediği hikayeyi panoramik şekilde deneyime dönüştürmektedir. 10 dakika süren 360 VR film, beyaz bir erkek çocuğun harabe bir okulda kara tahtaya çizdiği karalamalarla başlamaktadır. Íkinci sahnede siyah arka planda beyaz fontla yazılı “ikinci Dünya Savaşı'ndan bu yana dünya çapında yaklaşık 60 milyon insan işkence ve savaş yüzünden evlerinden sürülmektedir ve bu insanların yarısı çocuktur" bilgisi ekrana gelmektedir. "Bu film o çocuklardan üçünün hikayesidir" diyen yapım, bir kız çocuğunun mülteci kampı benzeri bir manzaraya bakması ve ardından gelen "Displaced" yazısıyla devam etmektedir.

Film, "geçen yıl Ukrayna'daki savaş sebebiyle Oleg ve ailesi köylerini terk etmek zorunda kaldı; savaş durduktan sonra evlerine geri döndüler" alt yazısıyla Oleg isimli 11 yaşında Ukraynalı erkek çocuğun yıkıntılar önünde verdiği pozla anlatı yönünü güçlendirmektedir. Savaş ve yıkım atmosferini çevresel görüntü eşliğinde deneyime dönüştüren video, Oleg ve arkadaşlarının yıkık bir çatının üzerinde oyun oynamasıyla öyküsünün görselini güçlendirmektedir. Oleg'in kendi ağzından ve ana dilinde sunduğu kişisel öyküsü görüntülerle birlikte akarken ikinci sekans ekrana gelmektedir. Chuol isimli 9 yaşındaki siyahi erkek çocuğun kaşlarını çatarak poz verdiği bu sekansta izleyiciye "Yaz boyunca Chuol'un köyü saldırıya uğradı. O ve büyükannesi bir adada yer alan bataklığa kaçtı" bilgisi verilmektedir. Dizlerine kadar su içinde duran Chuol, donuk ve sert bakışları ile elleri arkasında kameraya bakarken, su sesleriyle bezeli gergin müzik arka planda çalmaktadır. Oleg'de olduğu gibi kendi dilinde öyküsünü anlatan Chuol, eski bir sandalla suda yol almaktadır. Suda kürek çekerken köylerinin baskına uğradığını ve bataklığa kaçtıklarını anlatan Chuol, timsahlar tarafından yenmeyi savaşçılarla karşılaşmaya tercih edeceğini dile getirmektedir. Paradoks bir şekilde sakin su manzarası eşliğinde yaşadığı dehşeti ifade eden Chuol, o sabah annesinin gittiğini ve bir kargaşayla ayrıldıklarını söylemektedir. 
Görsel 1. "Displaced" kampanya içeriğinden kareler: Hana \& Chuol

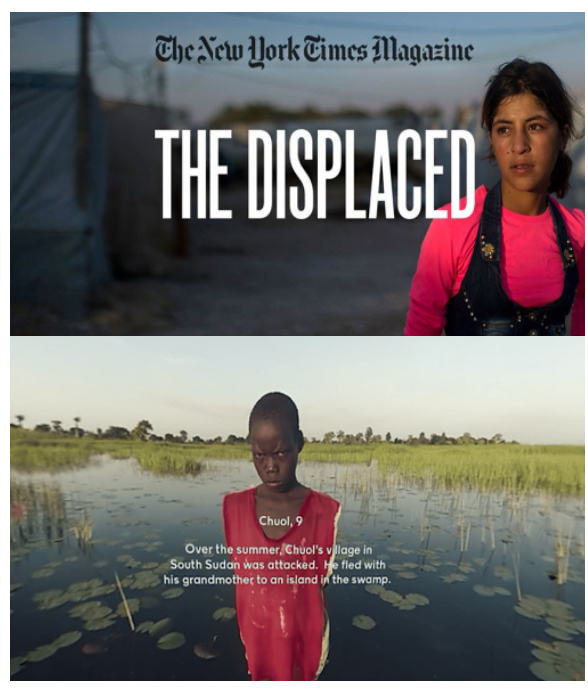

Diğer çocukların hikayesinde olduğu gibi benzer tema ve perspektif ile beliren üçüncü sekansta 12 yaşındaki Hana isimli Suriyeli kız çocuğunun görüntüsü ekrana gelmektedir. "2012 yılında Hana ve ailesi Suriye'yi terk etti. Şimdi onlar Lübnan'da yer alan mülteci yerleşkesinde yaşıyorlar" alt yazısıyla Hana, sarı ve kuru bozkır görüntüsünün önünde elleri önde bağlı bir şekilde poz vermektedir. Gergin ve donuk melodinin atmosferi beslediği bölüm, Hana'nın kendi hikayesini anlattığı alaca karanlık zaman diliminde canlandırma formatında akmaktadır. Kendi sesi ve diliyle mülteci yerleşkesindeki günlük rutinini anlatan Hana, Lübnanlıların kendilerini sevmediğini ve ülkelerinde istemediklerini ifade etmektedir. Her sabah iş için 04.00 'da kalktıklarını ve Suriye'deki savaşın bitmesini beklediklerini dile getiren Hana, traktör arkasına binen diğer mültecilerle birlikte görüntülenmektedir. Anlatı yönünü empati ile birleştiren bu sahne, tarlada çalışırken çekilen sahnelerle etkisini pekiştirmektedir. Bu yönüyle VR teknolojisi geleneksel medyanın ötesine geçen 360 derece görüntüleme ve izolasyon etkisiyle hikaye anlatma avantajını ve gerçeklik hissiyatını gözler önüne serebilmektedir.

Üç çocuğun hikayesini dönüşümlü bir şekilde anlatan kampanya, Hana'dan sonra Chuol'un yaşadıklarına geri dönmektedir. Yaşadığı yerde çok fazla insanın olduğunu ve yetkililerin yiyebilmeleri için onlara çuvalla yemek bıraktıklarını anlatan Chuol, sandalın içinde otururken mutsuz, ciddi ve donuk bir ifadeyle babası ve büyükbabasının evlerinde diri diri yakıldığını söylemektedir. Chuol'u, Oleg'in tarlada bir yetişkin kadınla çalıştığı sahneler izlemektedir. Oleg'de Chuol gibi büyükbabasının öldürüldüğünü ve bütün kış boyunca cesedinin bahçede kaldığını dillendirmektedir. Filmin başındaki yıkık okul bina görüntüsüne geri dönen Oleg ve arkadaşları "Savaş öncesinde öğretmenlerimiz bize bağırdıklarında okul hava- 
ya uçsa çok havalı olurdu" diye düşündüklerini -yıkılmış okullarının içinde eşelenirken- söylemektedir. Şimdi olsa asla böyle bir şey söylemeyeceklerini dile getiren Oleg, yine de arkadaşlarına sahip olduğu için memnun olduğunu iletmektedir.

Oleg'den sonra Hana'nın hikayesine geri dönülmekte; 12 yaşındaki kız çocuğunun mülteci arkadaşlarıyla birlikte iş dönüşü traktör arkasında yaptığı yolculuk ekrana gelmektedir. Suriye'de çok fazla sayıda oyuncak ve başka şeyler bıraktıklarını ancak şimdi sadece birbirlerine sahip olduklarını belirten Hana, sekansın geri kalanında harabe şeklindeki mülteci yerleşkesinde arkadaşlarıyla vakit geçirmektedir. Savaşın bitmesini ve eve dönmeyi dileyen Hana'yı bambaşka bir coğrafyadaki Chuol'un dileği takip etmektedir. Chuol'un gerçekliğine dönen video, 9 yaşındaki çocuğun "aslan" olup düşmanlarını yok etmek istediği söylemiyle devam etmektedir. Hana'yı ve Chuol'u, Oleg'in yıkık bir duvarın üstünde arkadaşlarıyla birlikte çekirdek çitlerken söylediği "ne olursa olsun bir daha asla evimi terk etmeyeceğim" sözü izlemektedir. Filmin başında olduğu gibi aynı görüntüler, pozlar ve ifadeler ile sırasıyla Oleg, Chuol ve Hana ekrana gelmekte ve Hana'nın arkasını dönüp yürüdüğü bozkır görüntüsüyle video sona ermektedir.

Üç farklı sekansta üç farklı coğrafyadan çocuğun hikayesini anlatan kampanya filmi, VR'ın -literatürde belirtilen- "3l" etkisini betimlemektedir. Kampanya örnekleminde VR teknolojisi, anlatının içine dalmak (immerse), etkileşim (interaction) yaşamak ve hayal gücünü (imagination) harekete geçirmek avantajlarıyla ikna gücünü ilişkisel tasarımla birleştirmektedir. Çocukların sesleri, görüntüleri ve ifadeleriyle içine dalınan kısa film, empati vaadini -geleneksel medyalara kıyasla- parasosyal iletişim tesiriyle daha kolay harekete geçirebilmektedir. Çevresel olarak kuşatılmış bir şekilde içine dalınan video ile bilgi toplumunun ihtiyaç duyduğu inandırıcıı boyutu daha gerçekçi bir tasvirle dile getirilebilmektedir. Halkla ilişkiler uygulayıcılarının intiyaç duyduğu bu tasvir, kişiselleştirilmiş pazarlama anlayışı ile yeni medya işleyişine de uygun görünmektedir. Bu bağlamda halkla ilişkiler uygulayıcıları ve medyaların (bu kampanya örnekleminde The New York Times'ın) VR'ı yenilikçi marka algısı yaratarak hedef kitleler ile daha etkili iletişim / ilişki kurabilme adına kullanmaları anlamlı gelmektedir.

Kamularla -Grunig ve Hunt'ın dillendirdiği- simetrik dil anlayışına uygun ilişki kurmak ve halkla ilişkiler algısını değiştirmek adına praksis değeri olan VR, çevrimiçi kamusal alanlarda anlatı biçimi yaratmak için de kullanılabilir görünmektedir. NYT'nin "Displaced" kampanyasından hareketle gazetecilik algısı üzerine de etkisi gözlemlenen VR, "hikaye anlatma şekli", "empati gücü" ve "güven tesisi" boyutlarında halkla ilişkileri dönüştürebilecek özelliklere; potansiyele sahip unsurlar içermektedir. Öte yandan araçsal olarak "deneyim değeri" yaratma işlevi ve "sanal varoluş" yönleriyle söz konusu VR kampanya, içeriği hazırlayan medyayı da (NYT Magazine) yenilikçi ve duyarlı gösterebilmektedir. 


\section{Samsung: "Be Fearless" \& "Bedtime Stories"}

Dijital dilin simülasyonla birleştiği Be Fearless" ve "Bedtime Stories kampanyaları, Oculus platformu temelinde gerçekleştirilen VR kampanyalar olarak dikkat çekmektedir. Samsung markasının kendi VR cihazı olan Samsung Gear'ı da besleyen iki kampanya, siber paralel gerçeklik içeren yönleriyle deneyime odaklanmaktadır. Psikolojik sorunlara yönelik çözüm öneren Be Fearless (Korkusuz OI) ile Samsung, kurumsal sosyal sorumluluk bilinciyle bireylerin yükseklik ve topluluk önünde konuşma korkularını yenmelerine yardımcı olmayı amaçlamaktadır.

360 derece görüntü teknolojisiyle hazırlanan deneyimlerle, topluluk önünde konuşma ve yüksekten atlama cesareti aşılanmak istenmektedir. "Samsung teknolojisiyle korkunun üstesinden gel" sloganıyla tanıtılan kampanyada dijital yerli kuşağın VR ile sunulan 3I (içine dalmak, etkileşim, hayal gücü) beklentisi karşılanmaktadır. Araç bileşenleri bağlamında ekran çağına ve mobil teknolojilere adapte olarak bilgi alan jenerasyona seslenen kampanya, hem 3D animasyon şeklinde hem de gerçek görüntüler eşliğinde kurgular içermektedir.

Topluluk önünde konuşma korkusunu yenmek adına sanal olarak tasarlanan kitle önünde yapılan konuşma deneyimi ve yükseklik korkusunu yenmek için hazırlanan yüksekten atlama videosu kampanyanın temel uygulama alanlarını oluşturmaktadır. VR uygulama (app) şeklinde yaratılan kampanyada farklı senaryolarda işlenen ve etkileşim içeren tasarımlar puanlama şeklinde sonuçlanmakta ve kullanıcıların başarı düzeyleri ölçülebilmektedir. VR'ın dört temel bileşeninin (sanal dünya, içine dalmak, duyusal geribildirim ve etkileşim) hepsini içeren kampanya, 3D olarak modellenen sanal dünya içeriği ile fiziksel ve zihinsel içine dalma (immerse) efekti yaratmaktadır.

Siber paralel gerçeklik yönü de olan kampanyada korkuların olmadığı bir gerçeklik yaratılmaya çalışılmış ve Samsung markasının kullanıcıların; tüketicilerin hayatında edindiği yer derinleştirilmek istenmiştir. İnovatif marka algısı inşa etmek adına tüketicilerin sorunlarına çözüm sunmak, hayatlarına dokunmak ve onlarla daha etkili / çeşitli iletişimler gerçekleştirmek kampanyanın örtük amacına hizmet etmektedir. Literatürde bahsedilen VR'ın var olma nedenlerinden basitleştirme, daha fazla bağ|ıık, yoğun satış döngüsü ve derin duygusal bağlılık işlevlerine atıfta bulunan kampanya, Gigante'nin (1993b, s. 14) ifade ettiği “bilişsel yük" boyutunu devreye sokmaktadır. Kullanıcının gerçeklik algısını sınayarak korkularını yenmesine yönelik paralel gerçeklik deneyimi sunan Samsung, sosyal sorumluluk bilincini teknoloji (VR) ve ürün (Samsung Gear) temelinde hayata geçirmektedir. Bu durum satış döngüsünü beslemesi, deneyim değeri sağlaması ve dolaylı yoldan pazarlama hedeflerine destek sunması açısından kampanyayı değerli hale getirmektedir. 
Görsel 2. Kampanyalardan kareler: "Be Fearless" \& "Bedtime Stories"

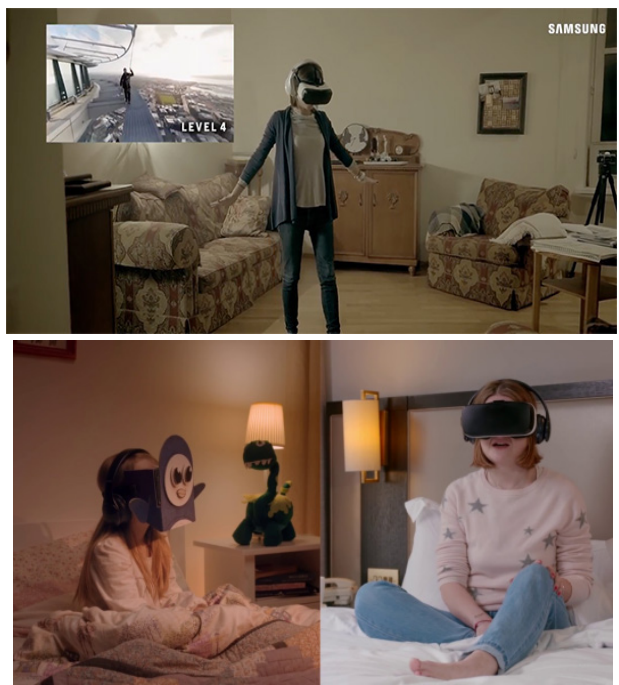

Samsung'un bir diğer kampanyası olan Bedtime Stories (Uyku Masalları)'de ise marka, uyku zamanı çocuklarının yanında olamayan ebeveynler için etkileşim temelli VR uygulama hazırlamıştır. "Uzaklığı azaltmak istedik" sloganıyla Samsung, ebeveynlerin ve çocuklarının VR gözlükler takarak 3D modellenmiş temsillerini ekrana aktarmaktadır. Uygulama içerisinde yer alan masalların metinlerini okuyabilen ebeveynler ve çocuklar masal içerisinde yer alan animasyonlarla küçük çaplı etkileşimlere geçebilmektedir. Tamamen 3D modellenmiş bir sanal dünyada hayali bir evreni çocuk ve ebeveyn için görünür hale getiren uygulama, sahip olduğu zihinsel dalış ve co-iletişim (birlikte iletişim) unsurlarıyla dikkat çekici görünmektedir. "Be Fearless" kampanyasında olduğu gibi VR avantajlarını tüm yönleriyle kullanan ve sosyal sorumluluk stratejisi içeren kampanya, hikaye anlatma şekli ve bağlılık bileşenleriyle halkla ilişkilerin ilişki yönetimi işlevini hatırlatmaktadır.

\section{TOMS: "Experience the TOMS Virtual Giving Trip"}

"Bir çift TOMS aldığında neler olur?" sorusuyla başlayan TOMS VR deneyiminde marka, aracın mesaj olduğu bir iletişim anlayışını benimsemektedir. Yenilikçi marka imajı sergilemek ve sosyal marka algısı yaratmak adına işlev üstlenen sanal TOMS deneyimi, marka değerlerini ve çağrışımlarını olumlama bağlamında değer arz etmektedir. VR'ın hikaye anlatma / içerik aktarma şekillerini çeşitlendirme, hedef kitleye ulaşmada deneyimsel, psikolojik ve interaktif yollar keşfetme, izolasyon ve soyutlama gibi etkiler sayesinde daha konsantre deneyimler sunabilme yönlerini baskın şekilde kullanan kampanya, 360 derece çekilmiş görüntülerle 
videonun başında sorduğu sorunun cevabını vermektedir. Hazırladığı kampanya ile VR teknolojisinin diyalektik gereğine uygun davranan TOMS markası, VR'ın halkla ilişkiler açısından gereğini açıklayan derin duygusal bağlılık ve artan güven bileşenlerini hayata geçirmektedir. Marka bu sayede -Bernays'ın dillendirdiği gibiseslendiği kamular açısından anlayış ilişkisine dayalı iki yönlü simetrik iletişimi anlamlı hale getirmektedir.

Görsel 3. "Experience the TOMS Virtual Giving Trip" kampanya görselleri

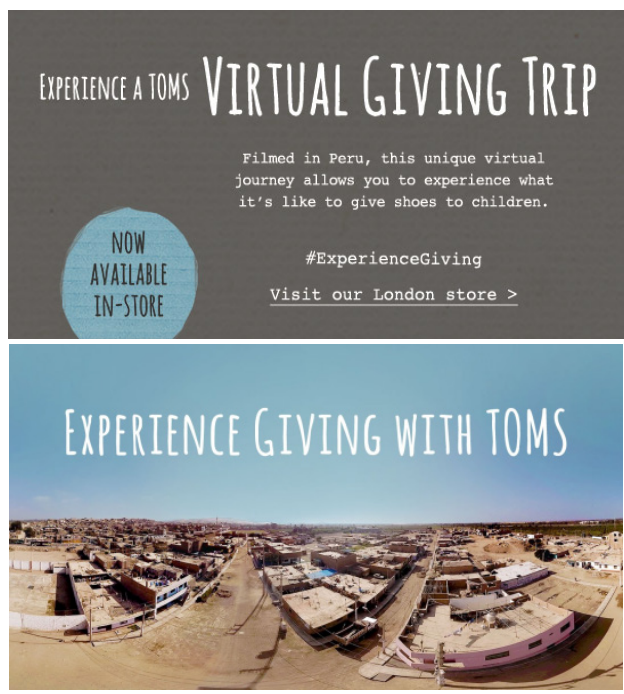

TOMS markasının kurucusu Blake Mycoskie'nin seslendirdiği VR deneyimde, Peru'nun kırsal ve gelişmemiş bir bölgesi gösterilmektedir. Drone ile çekilen görüntüler üzerine konuşan Blake Mycoskie, bir Arjantin gezisi sırasında ayakkabıları olmayan çocuklar gördügünden bahsetmektedir. Yardımcı olmak için "giving (bağış)" programını hayata geçirdiklerini ve ayakkabı sattıkları her firma için bir ayakkabı hediye ettiklerini anlatmaktadır. Peru'daki "Sanal Bağış Yolculuğu (Virtual Giving Trip)" deneyimini VR ortama aktaran marka, "giving partner (hediye partneri)" programı çerçevesinde bu ziyareti gerçekleştirdiğini ifade etmektedir.

TOMS tüketicisi ve ilgili kamulara yönelik hazırlanan deneyim, yeni kamusal alanlardan biri olan sosyal medya platformlarına (Youtube ve Within gibi) konarak geniş kitlelere ulaştııımaktadır. "Peru'ya hoş geldiniz" ifadesi ile araba içerisinde başlayan deneyim okul ziyareti ile devam etmektedir. Yaklaşık 4 dakika süren yolculuk deneyimi ip atlayan, ayakkabı deneyen çocuk görüntüleri ve TOMS temsilcisinin çocuklara ayakkabı giydirmesi; onlarla oyun oynaması ile sürmektedir. Sonraki sahnelerde çocuklardan biri olan Hulio'nun evine gi- 
den TOMS temsilcisi, çocukla evi hakkında konuşmakta ve çocuğun hikayesini izleyiciler için özetlemektedir. Hulio gibi okula gitmek için yürümek zorunda olan ve ayakkabıları olmayan çok sayıda çocuğun olduğunu ileten yetkili, okulun bahçesinde diğer çocuklarla oyunlar oynayarak dans ve sohbet etmektedir. Söz konusu sahneler VR'ın dalma etkisi ile oluşturduğu empati ilişkisini -geleneksel medyalarla sağlanamayacak formatta- gerçekçi kılmaktadır. VR kampanya “Dünyanın diğer bölgelerindeki ihtiyaç sahibi çocuklara ulaşmaya devam etmek için değerli desteklerinize ihtiyaç duyuyoruz, yürekten teşekkürler" diyen Mycoskie'nin sözleri ve TOMS temsilcisi kadın ile Hulio'nun samimi görüntüleri (el sallamaları ve beşlik çakmaları) ile sona ermektedir. Ilişki yönetimine atıfta bulunan söz konusu son, TOMS markasını sadece bir ayakkabı çağrışımından çıkarıp halkla ilişkiler açısından proaktif iletişimler sunan sosyal bir marka haline getirebilmektedir.

\section{Coca Cola: "Christmas Ride" \& "Recycled Cardboard"}

Christmas Ride (Noel Yolculuğu) kampanyasında Coca Cola, katılımcıları tamamen 3D şekilde tasarlanmış animasyon dünyada Noel yolculuğuna çıkarmaktadır. Noel Baba ve geyikleri eşliğinde Noel ve kış atmosferini sanal şekilde deneyimleme imkanı sunan kampanya, deneyim pazarlamaya uygun bir şekilde kültürel değerlere gönderme yapmaktadır. Dumanı tüten Amerikan evleri, karlı ve sisli kırsal doku, kırmızı Noel tonlu ışıklandırma, sarı ve parlak ay görsellerinin dikkat çektiği animasyon deneyimde iki geyiğe bağlı kızak ile Noel Baba eşliğinde gerçeküstü bir yolculuk yapılmaktadır. VR teknolojisinin temel fonksiyonu olan gerçekleşmesi imkansız sanal dünyalar ve deneyimler yaratma özelliği bu kampanyada uygulamaya dökülmektedir. Çoklu duyusal kanallar aracılığıyla gerçek zamanlı simülasyon ve etkileşimler tasarlamak bağlamında örnek teşkil eden kampanya, derin duygusal bağlılık sunma işlevini toplumun değerlerini ritüelleştirerek yerine getirmektedir.

Hareketli görüntüler ve ekran yönlendirmeleriyle ilerleyen VR videoda hayal gücü (imagination) ve dalmak (immerse) etkisi yoğun bir şekilde hissedilirken fonda çalan Noel müziği tematik işleyişi kuvvetlendirmektedir. Geyiklerin yol üzerinde Coca Cola tırlarının yanından geçmesi, tırların, geyiklerin geçişi sırasında korna çalması; geyiklerin havada uçarken önlerine kayaların çıkması, kaya parçalarının düşmesi içeriğin inandırıcılığının artması ve gerçeklik algısının eğlence ile birleşmesi adına önemli görünmektedir. Videonun sonunda Noel ışıklarıyla donatılmış, renkli Coca Cola tırlarının bulunduğu ve havai fişeklerin patlatıldığı başlangıç rotasına dönen geyikler, Charles Dickens'ın Christmas Carol (Bir Noel Şarkısı) romanını canlandırır şekilde yolculuğu tamamlamaktadır. Lemon \& Orange tarafından Coca Cola için geliştirilen kampanya Coca Cola Noel Tırları'nın turları esnasında gösterilmektedir. Kampanya ile marka, ürün / kültür arası ilişkiyi eşlenik hale getirmekte ve ekran çağına uygun iletişim sunarak yeni medya çağına uygun ilişki tesis edebilmektedir. 
Görsel 4. "Christmas Ride" \& "Recycled Cardboard" VR kampanyaları

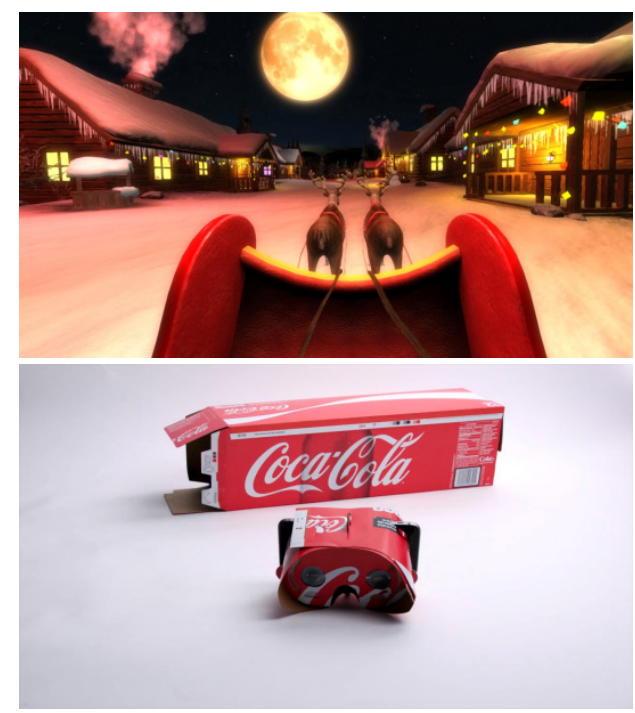

Öte yandan bir diğer Coca Cola VR kampanyası olan Recycled Cardboard (Geri Dönüştürülmüş Gözlük) ile marka, VR'a yönelik hazırladığı içerikleri hem sosyal sorumluluk girişimi ile birleştirmekte hem de yenilikçi yönünü vurgulayabilmektedir. Oyun tatmini gibi bir işleyiş̧le kutu tasarımlarının Cardboard'a dönüştüğü kampanyada, kola paketleri geri dönüşümlü malzemeden üretilmekte ve tüketici tarafından birleştirilmektedir. VR'ın halkla ilişkiler açısından var olma gerekçelerinden biri olan "satış döngüsü"ne de hizmet eden strateji, dünyanın ilk dönüştürülmüş VR görüntüleyicisi sloganıyla da markanın öncü rolünü pekiştirmektedir. Üç farklı şekilde (origami, custom, insert) birleştirilebilen tasarımlar, içerik yerine basit çaplı donanımı kampanyanın ana unsuru haline getirmektedir. Google Cardboard stili basit ve pratik VR görüntüleyici formatındaki söz konusu tasarım, geri dönüşüm içeren ambalaj boyutuyla sosyal pazarlama anlayışına da örnek sunmaktadır.

\section{UNICEF: “Clouds Over Sidra”}

Birleşmiş Milletler Çocuklara Yardım Fonu (UNICEF) tarafından hazırlanan, çocuk, savaş ve mülteci olmak üzerine odaklanan Clouds Over Sidra (Sidra'nın Üzerindeki Bulutlar) kampanyası, Castells'in ifade ettiği "Ağ Toplumu" deyişine atıfla küresel olarak egemen olan hedef kitleye ulaşmak adına önem taşımaktadır. Gerçek görüntüler eşliğinde 360 derece çekim tekniğini kullanan kampanya, Ürdün Za'atari'deki 84.000 Suriyeli mültecinin yaşam koşullarına 12 yaşındaki Suriyeli bir kız çocuğu (Sidra) üzerinden ayna tutmaktadır. Paradoks bir şekilde yeni medya teknolojilerine (Internet, VR başta olmak üzere) daha kolay erişebilen kamulara ses- 
lenen kampanya, toplumsal duyarsızlık sendromunu yenmek adına çağrıda bulunmaktadır. VR'ın anlatı formatı, etkili ve çeşitli iletişim kanalı, duyusal ve duygusal geribildirim potansiyeli gibi işlevlerini kullanmak isteyen kampanya, sosyal dili teknoloji dili ile sentezlemeyi amaçlamaktadır. Deneyim ekonomisi bağlamında bağış çağrısını yinelemek adına motive edici rol üstlenebilen VR film, halkla ilişkiler ve VR arası ilişkiyi duygusal çekicilik temelinde kurgulamaktadır. Derinlik hissi ve perspektif bağlamında panoramik görüntünün avantajını kullanan "Clouds Over Sidra", VR platformlarından biri olan Within üzerinden yayınlanmaktadır.

Görsel 5. "Clouds Over Sidra" afiş ve içerik görseli

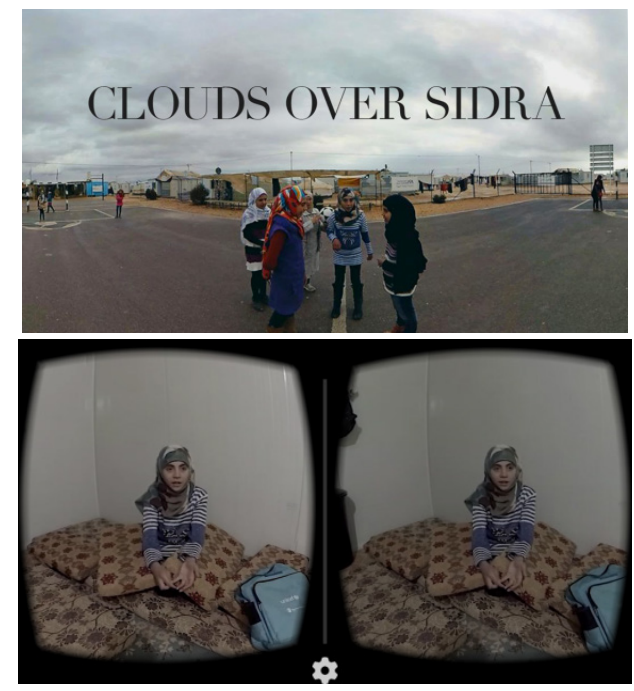

Çöl görüntüsüyle başlayan, Sidra'nın uçurtmasını Ürdün çöllerinde bıraktığını söylemesiyle devam eden VR film, Sidra ve ailesinin kamptaki sıradan bir gününü tek odalı evlerinden başlayarak görselleştirmektedir. 1,5 yıldır kampta kaldığını söyleyen Sidra'nın hikayesi fonda çalan piyano ve kamp sahneleriyle kurgulanmaktadır. Bulutlu günleri sevdiğini ifade eden Sidra, örtü benzetmesiyle bulutları neden sevdiğini açıklamaktadır. Kampanyanın başlığı olan bu metaforu, kamptaki derslik, fırın, çamurlu kamp bahçesi, kamp internet kafesi, kamp spor ve güreş bölümü, futbol sahası, akşam yemeği, çadır, kamp alanı ve alanda oyun oynayan çocuk sahneleri izlemektedir.

Kısa filmin başında gösterilen tek odalı kamp evine geri dönen son sahnede Sidra göz yaşları içerisinde "Bence 1,5 yıl burada kalmak için yeterli bir süre. Sonsuza kadar 12 yaşında olmayacağım ve burada kalmayacağım. Öğretmenim bulutların hareket ettiğini ve Suriye'den geldiklerini söylüyor. Bir gün bulutlar ve ben eve geri döneceğiz" demektedir. Üzerine siyah arka planda beyaz font ile "Dünya İkinci Dünya Savaşı'ndan bu yana en büyük mülteci kriziyle yüzleşiyor. Eylül 2015 
itibariyle Ürdün'deki Za'atari kampında savaş ve kıtlıktan kaçan 80.000 Suriyeli mülteci bulunuyor. Eve dönmenin ne zaman güvenli olacağını ve döndüklerinde onları neyin beklediğini kimse bilmiyor" bilgisi paylaşılmaktadır. UNICEF'in duygusal çekicilikle farkındalık yaratmak adına yayınladığı VR film, Chris Milk'in belirttiği VR'ın "nihai empati makinesi"ne dönüşmesi bağlamında teknik ve söylem açısından -verimli- olasılıklar içermektedir.

Enformasyon çağında halkla ilişkiler yönetimini "içeriğe dalmak (immerse)", "etkileşim (interaction) yaşamak" ve "hayal gücünü (imagination) harekete geçirmek" gibi temel işlevler içeren VR teknolojisini kullanarak gerçekleştiren markalar, tercih ettikleri içerik formatları, platform alternatifleri, açık ve örtük anlam çağrışımlarıyla ikna yöntemlerini çeşitlendirmektedir (Tablo 1). Yeni medya dili bağlamında kuşatılmış deneyimlerle marka-tüketici ilişkisini asimetrik boyuttan simetriğe dönüştüren söz konusu kampanyalar, VR karakteristiğini özetleyerek ilişkisel ve deneyimsel pazarlama adına örnekler sunmaktadır.

Sosyal amaçlı ve temalı VR kampanyaların yanında pazarlama amaçlı halkla ilişkileri kullanan VR kampanyalar da bulunmaktadır. Lowe's, Volvo, Thomas Cook, Oreo, McDonald's markaları, ifade edilen örneklem çerçevesinde pazarlama amaçlı VR kampanyalara sahip markalar olarak dikkat çekmektedir. Lowe's markasının "Holoroom" uygulaması, HTC Vive platformunu kullanarak müşterilerine 3D modellenmiş tasarım ve tadilat konularında yardımcı olan deneyimler sunmaktadır. Volvo, XC90 modelini tamamen 3D formatında tasarlanan VR uygulama üzerinden kendi hazırladığı VR Cardboard ile tanıtmaktadır. Birleşik Krallık merkezli bir seyahat ve turizm şirketi olan Thomas Cook VR uygulaması ile yolcularına uçmadan önce sanal denemeler yapma imkanı sağlamaktadır. Oreo hazırladığı VR reklam ile tüketicileri sanal dünya şeklinde yaratılan paralel bir Oreo diyarına davet etmektedir. McDonald's ise "Happy Goggles (Mutlu Gözlük)" adıyla -Coca Cola benzeri- VR başığına dönüşen "Happy Meal (Mutlu Yemek)" ambalajını ve çocuklara yönelik "Happy Meal VR" oyununu tanıtmıştır. 
Tablo 1. VR teknolojisini kullanan halkla ilişkiler kampanyaları ve kampanyaların iletişim dilleri

\begin{tabular}{|c|c|c|c|c|}
\hline $\begin{array}{l}\text { VR } \\
\text { kampanyalar }\end{array}$ & $\begin{array}{l}\text { VR içerik } \\
\text { formatı \& } \\
\text { platform } \\
\end{array}$ & \begin{tabular}{|l} 
Halkla ilişkiler bağı \& \\
iletişim tasarımı
\end{tabular} & Açık içerik & Örtük içerik \\
\hline $\begin{array}{l}\text { "Displaced" } \\
\text { (New York } \\
\text { Times) }\end{array}$ & $\begin{array}{l}360 \text { VR film } \\
\text { (10 dk.) } \\
\text { NYT VR app } \\
\text { NYT Youtube }\end{array}$ & $\begin{array}{l}\text {-Reaktif halkla ilişsiler } \\
\text {-Parasosyal iletişim } \\
\text {-Kurumsal sosyal } \\
\text { sorumluluk (savaş ve } \\
\text { çocuklar) } \\
\text {-Kamu faydası } \\
\text {-Öyküleştirme } \\
\text {-Empati dili }\end{array}$ & $\begin{array}{l}\text {-Çocuk işçiler } \\
\text {-Ÿıık binalar } \\
\text {-Ülkelerin } \\
\text { coğrafyası ve doğal } \\
\text { güzellikleri } \\
\text {-Mülteci kampı } \\
\text {-3 çocuk (Oleg, } \\
\text { Hana ve Chuol) } \\
\text {-Çocuk oyunları } \\
\text {-Yardım çuvalları }\end{array}$ & \begin{tabular}{|l}
-Çocuk hakları \\
-Savaş \\
-Mültecilik \\
-Küresel ilişki \\
ağı \\
-Yoksulluk \\
-Çocuk hayal \\
dünyası
\end{tabular} \\
\hline $\begin{array}{l}\text { "Be Fearless } \\
\text { \& Bedtime } \\
\text { Stories" } \\
\text { (Samsung) }\end{array}$ & $\begin{array}{l}\text { 3D VE (virtual } \\
\text { enviroment) } \\
\text { VR } \\
\text { Oculus } \\
\text { Samsung Gear }\end{array}$ & $\begin{array}{l}\text {-Kurumsal sosyal } \\
\text { sorumluluk (fobiler ve } \\
\text { aile iletişimi) } \\
\text {-Oyunlaştırma } \\
\text {-İnteraktif katılım } \\
\text {-Simülasyon } \\
\text {-Co-iletişim }\end{array}$ & $\begin{array}{l}\text {-Toplantı odası } \\
\text {-Yüksek binalar } \\
\text {-Puanlama çizelgesi } \\
\text {-Çocuk odası } \\
\text {-Masal kitapları }\end{array}$ & $\begin{array}{l}\text {-Kişisel gelişim } \\
\text {-Terapi } \\
\text {-Duygusal } \\
\text { bağlılık } \\
\text {-illgili ebeveyn } \\
\text {-Yaratıcılık ve } \\
\text { inovasyon }\end{array}$ \\
\hline $\begin{array}{l}\text { "Virtual Giving } \\
\text { Trip" } \\
\text { (TOMS) }\end{array}$ & $\begin{array}{l}360 \text { VR film (4 } \\
\text { dk.) } \\
\text { TOMS } \\
\text { Youtube } \\
\text { Within }\end{array}$ & $\begin{array}{l}\text {-Proaktif iletişim } \\
\text {-Kurumsal sosyal } \\
\text { sorumluluk (yoksulluk, } \\
\text { eğitim ve çocuk) } \\
\text {-Kamu faydası } \\
\text {-Öyküleştirme } \\
\text {-Empati dili }\end{array}$ & $\begin{array}{l}\text {-Otomobil yolculuğu } \\
\text {-Peru kırsalı } \\
\text {-TOMS ayakkabılar } \\
\text {-Okul ziyareti } \\
\text {-Köy yaşamı } \\
\text {-ip atlama, dans, } \\
\text { futbol }\end{array}$ & $\begin{array}{l}\text {-Bağış takibi } \\
\text {-Güven } \\
\text {-Yoksulluk } \\
\text {-Çocuk ve } \\
\text { eğitim hakları } \\
\text {-Sosyal marka } \\
\text {-Yenilikçi ve } \\
\text { ilgili marka } \\
\text { algısı }\end{array}$ \\
\hline $\begin{array}{l}\text { "Christmas } \\
\text { Ride \& } \\
\text { Recycled } \\
\text { Cardboard" } \\
\text { (Coca Cola) }\end{array}$ & $\begin{array}{l}\text { 3D VE (virtual } \\
\text { enviroment) } \\
\text { VR \& Google } \\
\text { karton VR } \\
\text { Oculus }\end{array}$ & $\begin{array}{l}\text {-Oyunlaştırma } \\
\text {-Kurumsal sosyal } \\
\text { sorumluluk (Noel ve } \\
\text { geri dönüşüm) } \\
\text {-Reaktif halkla ilişkiler } \\
\text {-Oyunlaştırma } \\
\text {-Simülasyon } \\
\text {-Interaktif katılım }\end{array}$ & $\begin{array}{l}\text {-Noel Baba, ren } \\
\text { geyikleri, kızak } \\
\text {-Ay, şehir ışıkları, } \\
\text { duman } \\
\text {-Amerikan evleri, } \\
\text { kış, kar } \\
\text {-Coca Cola tırları } \\
\text {-Coca Cola } \\
\text { cardboard }\end{array}$ & \begin{tabular}{|l}
-Kültürel \\
temas \\
-Noel ritüelleri \\
-Duygusal \\
bağllılı \\
-Sosyal marka \\
-Geri dönüşüm \\
-inovasyon
\end{tabular} \\
\hline $\begin{array}{l}\text { "Clouds Over } \\
\text { Sidra" } \\
\text { (UNICEF) }\end{array}$ & $\begin{array}{l}\text { 360 VR film (8 } \\
\text { dk.) } \\
\text { UNICEF } \\
\text { Youtube }\end{array}$ & $\begin{array}{l}\text {-Kurumsal sosyal } \\
\text { sorumluluk (savaş, } \\
\text { mültecilik ve çocuklar) } \\
\text {-Kamu faydası } \\
\text {-Öyküleştirme } \\
\text {-Empati dili }\end{array}$ & $\begin{array}{l}\text {-Ürdün, çöl } \\
\text { görüntüsü } \\
\text {-Mülteci kampı } \\
\text {-Konteyner oda } \\
\text {-1 çocuk (Sidra) } \\
\text {-Akşam yemeği, } \\
\text { çadır, kamp alanı }\end{array}$ & \begin{tabular}{|l}
-Bulut \\
metaforu ve \\
çocuk hayalleri \\
-Çocuk hakları \\
-Savaş \\
-Mültecilik \\
-Küresel ilişki \\
ağı \\
-Yoksulluk
\end{tabular} \\
\hline
\end{tabular}




\section{Değerlendirme ve Sonuç}

Yeni medya teknolojilerinden biri olan VR'ın halkla ilișkiler uygulayıcıları tarafından nasıl kullanılığını hayata geçirilen VR kampanyalar üzerinden analiz etmeyi amaçlayan çalışmada, Google ekranında ilk sayfada görüntülenen başarılı VR kampanyaları incelenmiştir. Araştırmada ifade edilen amaç ve yöntem çerçevesinde Google ekranında birinci sayfada çıkan The NYT Magazine, Samsung, TOMS, Coca Cola ve UNICEF markalarının / kurumlarının sosyal sorumluluk ve kamu faydası temalı VR kampanyaları yorumlayıcı içerik analizi ile analiz edilmiştir. Söz konusu sosyal sorumluluk temalı kampanyaların yanı sıra pazarlama amaçIı halkla ilişkiler dilini kullanan Lowe's, Volvo, Thomas Cook, Oreo, McDonald's markalarının VR deneyimleri de halkla ilişkiler pratiğini / algısını yeni medya çağına uyumlu hale getirebilmektedir. Incelenen VR kampanyalarda sosyal dil ve pazarlama amaçlı iki (açık) ana temanın uygulamaya döküldüğü gözlemlenmektedir.

Hedef kitleler ile etkili iletişim yöntemleriyle buluşmayı amaçlayan markalar, yenilikçi araçlardan biri olan VR teknolojisini proaktif ve reaktif bir şekilde kullanmaktadır. Dünyanın önde gelen markaları VR'ın 3l etkisini (içine dalmak, etkileşim ve hayal gücü) araştırılan kampanyalar dahilinde uygulamaya dönüştürmektedir. Katılım süresi, derin duygusal bağlııı, artan güven, basitleştirme, daha fazla bağılıık ve yoğun satış döngüsü avantajlarıyla VR, halkla ilişkiler uygulayıcıları tarafından benimsenmektedir. Çevrimiçi kamu alanı olan İnternet'ten erişilebilen söz konusu kampanyalar, hikaye anlatma şekli, empati, deneyim / etki gücü, medya iletişimi ve yenilikçi marka konumlama değişkenleriyle halkla ilişkilerin praksis değerini güncelleyebilmektedir. Grunig ve Hunt'ın ifade ettiği karşılıklı dengeli simetrik iletişim anlayışına sadık kalan VR kampanyalar, yarattığı deneyimlerle empati yönünü güçlendirmektedir. Kitlesizleştirme ve/veya kişiselleştirme bağlamındaki yeni medya modern diline uygun şekillenen kampanyalar, elde etmek istediği hedefleri VR'ın avantajlarını kullanarak hayata geçirebilmektedir.

Markalar tarafından 360 derece çekilen görüntülerle tasarlanan VR kampanyaların ağırlıkta olduğu tespit edilmiş, 3D modellemelerin hayal gücü temasının ağırlıkta olduğu durumlarda kullanıldığı görülmüştür. Psikolojik etki açısından duygusal çekiciliklerin yoğun olarak kullanıldığı kampanyalarda (Displaced, Be Fearless, Virtual Giving Trip, Clouds Over Sidra), gerçek görüntülerin ve hayattan öykülerin tanıkların ağzından sinematik dille aktarılması, VR'ın inandırıcılık, empati ve anlatı yönünü vurgulamaktadır. Öte yandan animasyonlarla sanal dünya yaratan kampanyalar (Christmas Ride, Bedtime Stories) gerçeküstü içerikleri deneyime dönüştürerek VR'ın hayal gücü işlevini devreye sokabilmektedir.

Kamu faydasını gözettiklerini mülteci, savaş, çocuk hakları, korku, kültürel değerler konularını işleyerek vermeye çalışan markalar, halkla ilişkilerin ilişki yönetimi işlevine atıf içermektedir. Gündem aşısını yenilikçi dille yapan markalar, dolaylı biçimde inovatif marka konumlaması yaparak sorumlu reaktif iletişim anlayışını -özellikle Clouds Over Sidra ve Displaced kampanyalarında- uygulamaya 
dönüştürmektedir. Halkla ilişkiler ve VR teknolojisi kesişiminde öne çıkan unsurlardan olan katılım, bağlıık ve güven incelenen kampanyalarda görünür bir nitelik kazanmaktadır. Halkla ilişkilerin teknoloji ile entegrasyonunu sosyal dille kurgulaması kamular arasında ilişki kurma çabasına destek sunabilmektedir. Bu durum da sürekli güncellenen yeni medya araçlarının halkla ilişkiler uygulayıcıları tarafından nasıl ve ne yönde kullanılması gerektiğine dair ipuçları sunmaktadır.

\section{Kaynakça}

Ahuvia, A. (2001). Traditional, interpretive, and reception based content analyses: Improving the ability of content analysis to address issues of pragmatic and theoretical concern. Social Indicators Research, 54(2), 139-172.

Barnes, J. S. (2016). Understanding virtual reality in marketing: Nature, implications and potential. Available at SSRN: https://ssrn.com/abstract $=2909100$

Berg, B. L. (2001). Qualitative research methods for the social sciences (4th ed.). Boston, MA: Allyn and Bacon.

Biocca, F. (1992). Virtual reality technology: A tutorial. Journal of Communication, 42(4), $23-72$.

Bucher, J. (2018). Storytelling for virtual reality: Methods and principles for crafting immersive narratives. New York: Routledge.

Burdea, G. C. and Coiffet, P. (2003). Virtual reality technology. NJ: John Wiley \& Sons.

Chen, X. and Ding, G. (2009). New media as relations: Special commentary. Chinese Journal of Communication, 2(3), 367-379.

Duhé, S. (2015). An overview of new media research in public relations journals from 1981 to 2014. Public Relations Review, 41(2), 153-169.

Fuch, P. and Guitton, P. (2011). Introduction to virtual reality. In P. Fuchs, G. Moreau and P. Guitton (Eds.), Virtual reality: Concepts and technologies (pp. 3-10). USA: CRC Press.

Giarelli, E. and Tulman, L. (2003). Methodological issues in the use of published cartoons as data. Qualitative Health Research, 13(7), 945-956.

Gigante, M. A. (1993a). Virtual reality: Enabling technologies. In R. A. Earnshaw, M. A. Gigante and H. Jones (Eds.), Virtual reality systems (pp. 15-25). London: Academic Press.

Gigante, M. A. (1993b). Virtual reality: Definitions, history and applications. In R. A.Earnshaw, M. A. Gigante and H. Jones (Eds.), Virtual reality systems (pp. 3-14). London: Academic Press.

Graneheim, U. H. and Lundman, B. (2004). Qualitative content analysis in nursing research: Concepts, procedures and measures to achieve trustworthiness. Nur- 
se Education Today, 24(2), 105-112.

Gutierrez, M., Vexo, F. and Thalmann, D. (2008). Stepping into virtual reality. London: Springer.

Guttentag, D. A. (2010). Virtual reality: Applications and implications for tourism. Tourism Management, 31(5), 637-651.

Heisley, D. D. (2001). Visual research: Current bias and future direction. Advances in Consumer Research, 28, 45-46.

Hsieh, H. F. and Shannon, S. E. (2005). Three approaches to qualitative content analysis. Qualitative Health Research, 15(9), 1277-1288.

Jerald, J. (2016). The VR book: Human-centered design for virtual reality. NY: Morgan \& Claypool.

Johnson, M. A. (1997). Public relations and technology: Practitioner perspectives. Journal of Public Relations Research, 9(3), 213-236.

Kelleher, T. and Sweetser, K. (2012). Social media adoption among university communicators. Journal of Public Relations Research, 24(2), 105-122.

Kent, M. L. and Saffer, A. J. (2014). A Delphi study of the future of new technology research in public relations. Public Relations Review, 40(3), 568-576.

Kerrebroeck, V. H., Brengman, M. and Willems, K. (2017). When brands come to life: Experimental research on the vividness effect of virtual reality in transformational marketing communications. Virtual Reality, 21(4), 177-191.

Ma, J. Y. and Choi, J. S. (2007). The virtuality and reality of augmented reality. Journal of Multımedia, 2(1), 32-37.

Mahrer, N. E. and Gold, J. I. (2009). The use of virtual reality for pain control: A review. Current Pain and Headache Reports, 13(2), 100-109.

Mandal, S. (2013). Brief introduction of virtual reality \& its challenges. International Journal of Scientific \& Engineering Research, 4(4), 304-309.

Mayring, P. (2014). Qualitative content analysis: Theoretical foundation, basic procedures and software solution. Open Access Repository. Klagenfurt.

Merkl-Davies, D., Brennan, N. and Vourvachis, P. (2011). Text analysis methodologies in corporate narrative reporting research. Paper presented in the 23rd CSEAR International Congress on Social and Environmental Accounting Research, St. Andrews, 7-9 September.

Parisi, T. (2015). Learning virtual reality: Developing immersive experiences and applications for desktop, web, and mobile. USA: O'Reilly Media, Inc.

Pimentel, K. and Teixeira K. (1995). Virtual reality: Through the new looking glass, New York: McGraw-Hill Inc.

Porter, L. V., Trammell, K. D. S., Chung, D. and Kim, E. (2007). Blog power: Exa- 
mining the effects of practitioner blog use on power in public relations. Public Relations Review, 33(1), 92-95.

Potter, W. J. and Levine-Donnerstein, D. (1999). Rethinking validity and reliability in content analysis. Journal of Applied Communication Research, 27, 258-284.

Seale, C. and Tonkins, F. (2012). Content and comparative keyword analysis. In C. Seale (Ed.), Researching society and culture (pp. 459-478). London: Sage.

Sherman, W. R. and Craig, A. B. (2003). Understanding virtual reality: Interface, application, and design. San Francisco, CA: Morgan Kaufmann Publishers.

Sweetser, K. D. (2010). A losing strategy: The impact of nondisclosure in social media on relationships. Journal of Public Relations Research, 22(3), 288-312.

Vercic, D., Vercic, A. T. and Sriramesh, K. (2015). Looking for digital in public relations. Public Relations Review, 41 (2), 142-152.

Wapler, M. and Stallkamp, J. (1998). Virtual reality concepts and their description. Minimally Invasive Therapy \& Allied Technologies, 7(2), 85-87.

Ye, L. and Ki, E. J. (2012). The status of online public relations research: An analysis of published articles in 1992-2009. Journal of Public Relations Research, 24(5), 409-434.

Yoh, M. (2001). The reality of virtual reality. In Seventh International Conference on Virtual Systems and Multimedia (VSMM'01), Organized by Center for Design Visualization. Berkley, USA: University of California Berkley.

Zhao, S. (2006). The Internet and the transformation of the reality of everyday life: Toward a new analytic stance in sociology. Sociological Inquiry, 76(4), 458474.

Alaimo,K.(2016).http://apps.prsa.org/intelligence/Tactics/Articles/ view/11364/1121/A_New_Reality_6_Ways_VR_Can_Transform_Public_Relat\#. Wv3gITSFPIX

http://www.irispr.com/blog/pr-meets-vr-when-storytelling-becomes-virtual (Erişim Tarihi: 27.03.2018).

http://media.dmnews.com/documents/225/mslgroup_vr_ebook_56132.pdf (Erişim Tarihi: 24.03.2018). 